\author{
S. M. STOVPNYK ${ }^{1 *}$, H. K. TUHANOV ${ }^{2}$ \\ ${ }^{1 *}$ National Technical University of Ukraine "Igor Sikorsky Kyiv Polytechnic Institute", 37, prosp. Peremohy, \\ Kyiv, Ukraine, 03056, tel.+38 (050) 31078 25, e-mail stansto@ i.ua, ORCID 0000-0001-8053-2653 \\ ${ }^{2}$ National Technical University of Ukraine "Igor Sikorsky Kyiv Polytechnic Institute", 37, prosp. Peremohy, \\ Kyiv, Ukraine, 03056, tel.+380999654631, e-mail girey007@gmail.com, ORCID 0000-0002-8048-0635
}

\title{
ANALYSIS OF THE COMBINATION OF METHODS OF FASTENING THE JUNCTION POINT OF A HORIZONTAL TUNNEL WITH A VERTICAL SHAFT IN CONDITIONS OF DENSE URBAN DEVELOPMENT
}

Purpose. The problem of compares the long-term behavior of a tunnel-well taking into account the rigid and flexible couplings in the projected structures in Ukraine with $3 \mathrm{~d}$ digital modeling using the three-dimensional finite element method. A refined geotechnical model has also been developed, taking into account the nature of the piezometric starting conditions and the proposed piezometric conditions for assessing the long-term condition as well as a summary of the properties and dimensions of the tunnel and the shaft. Methodology. Analysis of structural connections based on the experience of building shallow subways in dense urban development on the example of construction projects in China and Mexico. Search for the optimal combination of implemented methods to achieve the optimal result. Problems of a choice of a mode with $3 \mathrm{~d}$ digital modeling using the three-dimensional finite element method based on two assumptions; the first assumption considers the rigid connection as a monolithic concrete structure between the shaft wall and the tunnel body, and the second assumption considers a material with elastic behavior between the two structures, which in turn leads to a flexible connection. The main parameters that must be clarified and corrected by the designer of the system during commissioning are determined. Next, the soft soil model was used to perform the analyzes with end elements for compressible layers. Findings. Simulation in the application, the Plaxis software environment obtained graphs of transients for the most important operating parameters, such as the geometry of the tunnel and the indicated lining, the flotation pool, three-dimensional clusters. Originality. Scientific interest in advancing technologies used in combination. Development of an algorithm for the optimal selection of the parameters of flexibility and durability in specific conditions, to save time and simplify the calculation forms. Practical value. The analysis of the obtained results is carried out, the main focus was on the relative loads and stress concentrations in the connecting elements, namely the stresses that occur in the transverse direction of the joint. Also in articles were determined some of the advantages and disadvantages of the different connection alternatives are discussed in order to neutralize the impact of the case in the future.

Keyword: tunnel-shaft connection; rigid connection; flexible connection; soft soils; regional settlements

\section{Introduction}

Since the 1970s, urban development in many cities has steadily grown and expanded. Due to the high population of large cities, as well as with a high population density, the desire for environmental friendliness and speed in relation to ways of transporting passengers, engineers and scientists began to look for more effective ways to implement such solutions. The general analysis of the problem considered on the method of a threedimensional model using the finite element method considers 2 basic models of connections in a structure with two different methods of mounting the structure. The first assumption considers the (C) S. M. Stovpnyk, H. K. Tuhanov, 2021 rigid connection as a monolithic concrete structure between the shaft wall and the tunnel body, and the second assumption considers a material with elastic behavior between the two structures, which in turn leads to a flexible connection. The very same sinking technology provides for 2 methods. Driving, first of all, the shaft and cross-joining the tunnel to it, and the second option - tunneling and joining the shaft to it last.

\section{Purpose}

The purpose of this article is to present the models of the distribution of loads and stresses in two types of joints (rigid and flexible), the use in the case of a flexible connection of the technology 
of the latest development of a flexible ring made of high-strength steel and polymer, a combination of the shaft-tunnel driving method, as well as an analysis of this situation based on on the comparison of the results obtained and their own comments and suggestions based on this comparison. Since this article is of an overview nature, then all data on geology and geological conditions are averaged, the description is theoretical and needs an actual field experiment. The example of a subway station based in China was taken as a basis.

\section{Methodology}

In their scientific paper (Jinxing Lai, et al., 2017) analyzed the technological characteristics of these two construction methods for the construction of a mine passage on the section of the tunnel between Zhanglu station and Shen Xin road station, China. They suggested that the "parallel bore with cross bore" method was better suited to good geological conditions under the bottom of the bore and discussed the advantages of this method. Taking into account the stability of the shaft and passability. There was evidence of damage to the connection between the tunnel and the well, built of soft clay. Therefore, it is important to use methods that take into account the more specific parameters of the study site and the structures involved, and thus allow the long-term settlement and stress distribution to be predicted as accurately as possible. An alternative to assessing the borehole-tunnel relationship is the use of finite elements (FEM). However, in the conditions of the geology of the Kiev region, it was suggested that it was impossible to implement such a method due to differences in soils and the depth of the tunnel body.

Based on the data obtained in the work (Song, Yang, \& Jiang, 2016), it was decided to abandon the technology of parallel tunneling (Do, Dias, Oreste, \& Djeran-Maigre, 2014) and tunneling and resort to a combination of these methods.

Tunnel and well characteristics. General tree properties. This shaft is of the "floating" type and therefore it needs constant drainage. Similar conditions are observed in the northern part of the city of Kiev, districts of troeshchyna and winegrower.
It also consists of a partition that is filled with cement mortar, which in turn protects against deep fracture and lifting forces.

Fig. 1 shows the geometric diagram of the shaft, which we are analyzing, as well as the dimensions and characteristics indicated above, which are conditional due to the overview nature of the article.

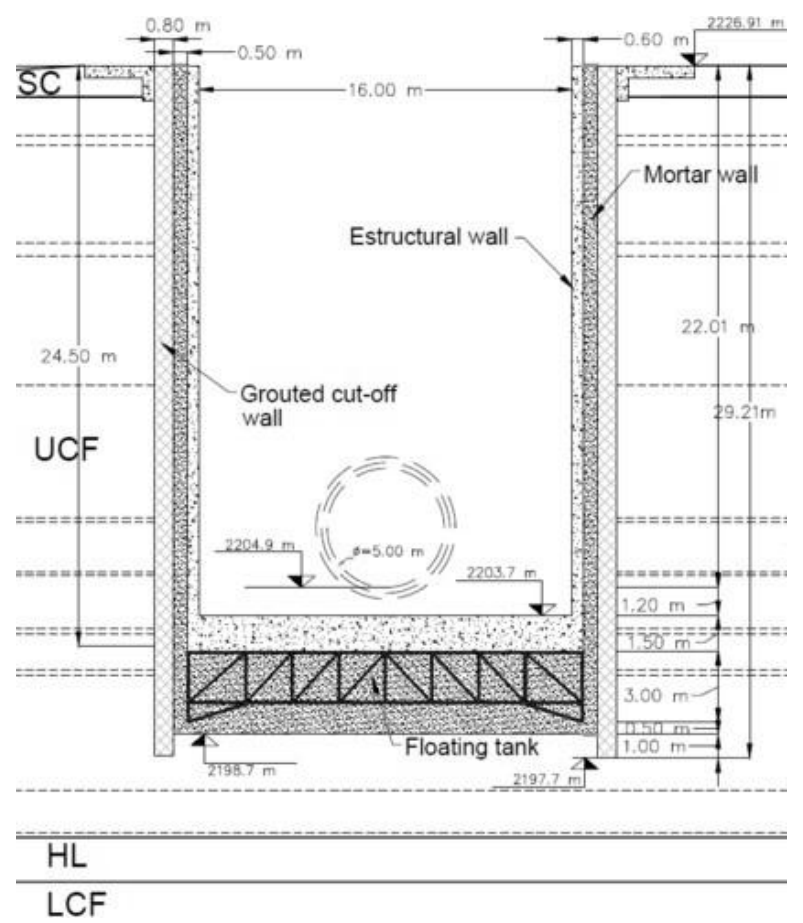

Fig. 1. Geometric scheme of shaft, source elaborated by author based on (Flores, Gordillo, Enríquez, De la Rosa, \& Guasch, 2016)

Next, we will select methods for covering the tunnel with an insulating material to prevent the harmful effects of groundwater, which will be based on seismic analysis. Such effects include longitudinal bending of the tunnel, compression and expansion of structures, and local deformation in the section plane of the structure or the oval of the tunnel-trunk (Jinxing Lai, Haobo Fan, Bangzhe Liu, \& Tong Liu, 2011).

Such changes and deformations are usually presented in the form of an analytical model of the beam and can be easily eliminated by means of block fastening or division of the site into expansion joints. For a qualitative calculation of internal deformations in the rock mass and structure, I use the seismic intensity method and the soil-structure interaction method using the displacement and displacement-response method. 
The influence of the soil and its structure on the structure must always be taken into account and in no case should it be neglected. For now, the conclusions of the article will have only a recommendatory and analytical character based on the experience of field measurements.

General characteristics of the tunnel. The analyzed tunnel is composed of two tunnel linings: first is a primary lining containing a ring with 6 segments and a secondary lining containing a reinforced concrete ring continuously, due to geotechnical conditions. On site and the geometry required for the drainage system.

The diameter inside the tunnel $-5 \mathrm{~m}$. The thickness of the primary segmental lining $-0.25 \mathrm{~m}$, and the final thickness $-0.30 \mathrm{~m}$. The concrete that was designed for the segmental lining consists of limestone aggregate, and the concrete for the final lining is basalt aggregate. Structural concrete for shaft and tunnel is calculated with f' $c=350 \mathrm{~kg} /$ $\mathrm{cm}^{2}$.

But it is worth considering the fact that the construction of the tunnel is carried out by mechanical methods of TBM type EPB (Earth Pressure Balance) (Song, Yang, \& Jiang, 2016).

The design of a flexible insert will also be used according to a new method that has proven itself in China.

The method consists in assembling, at the construction stage, a connecting element in the form of a ring, which creates a flexible structure that will take on the corresponding displacements in the vertical and horizontal vectors when the array changes and with further vibrations from the subway trains. The method involves placing high strength stainless steel (SUS) plates over the shaft and parts. The space between these plates is filled with an elastic element (section $50 \times 50 \mathrm{~mm}$ ) (twocomponent polyurethane seal), which ensures high efficiency.

His method can be used in the event of a relative displacement (expansion and contraction displacement) of $25 \mathrm{~mm}$ or less during an earthquake. From repeated deformations.indicated lining.

General considerations about the 3D model Construction Procedures. The two methods for constructing the section of the tunnel between stations were the "cross-pass shaft construction" method (hereinafter referred to as Method 1) and the "cross-pass parallel shaft construction" method (hereinafter referred to as method 2).

In both methods, the construction of the shaft intersection and the crossing passage was divided into three phases: the construction of the blocking section, construction of the shaft well, and the upper passage and ledge of the horse head structure (Vahed, G., et al., 2010). According to the design scheme, a drainage well was to be arranged to advance the drainage of the site before the shaft was excavated so that the construction of the shaft and the cross passage could be carried out in dry soil. The construction sequence of Method 2 is shown in Fig. 2.

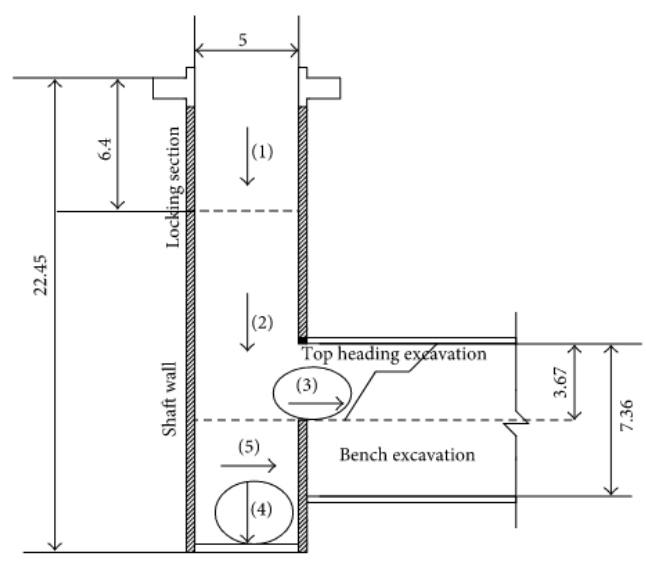

Fig. 2. Construction sequence of Method based on source (Cárdenas, 2016)

However, if you swap the positions of steps 3 and 4 in the construction sequence shown in fig. 3 , the diagram would describe the construction sequence of Method 1.

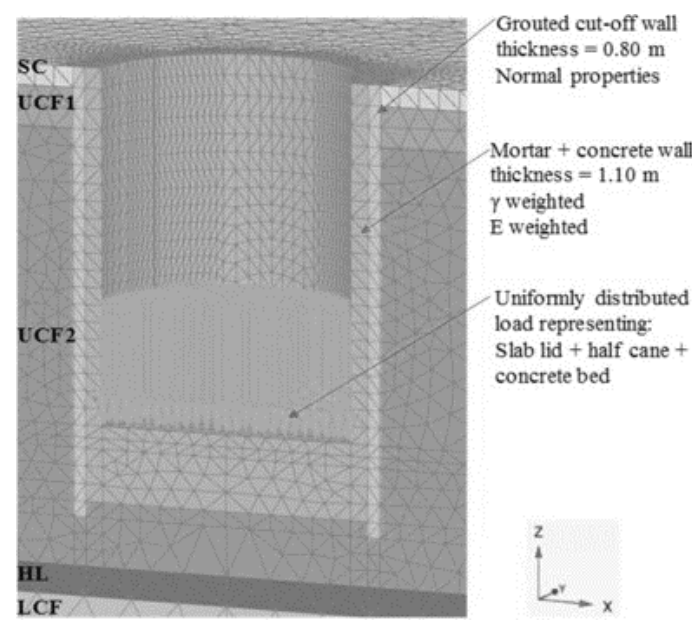

Fig. 3. Geometric shaft arrangement 3D model based on source (Arnau, \& Peña, 2014) 
Thus, the main difference between the two method constructions was the excavation sequence of the top header horse heads. In Method 1, the horsehead was excavated after a portion of the trunk was dug below the top face, but in Method 2, the horsehead was completed before a portion of the trunk was dug below the top face (Jinxing Lai, Haobo Fan, Bangzhe Liu, \& Tong Liu, 2011).

These two methods caused different distribution of stresses and strains in the surrounding rock and had different spatial impacts on construction safety.

Loads on the roof covering, half-beam and concrete base (internal structures of the well) are replaced by an evenly distributed load. The beam is designed for the 3D model (Zaldivar, Rodríguez, \& Auvinet, 2012), and the joint wall remains with its original characteristics. Fig. 3 shows the idealized tree geometry for 3D analysis.

A composite structure with a thickness corresponding to the sum of the two coatings (primary and secondary) with cementitious properties and weighted modulus of elasticity (E) under long-term conditions was also considered for the tunnel. Fig. 4 shows the geometric arrangement of the tunnel connected to the borehole in the 3D model (Flores, Gordillo, Enríquez, De la Rosa, \& Guasch, 2016).

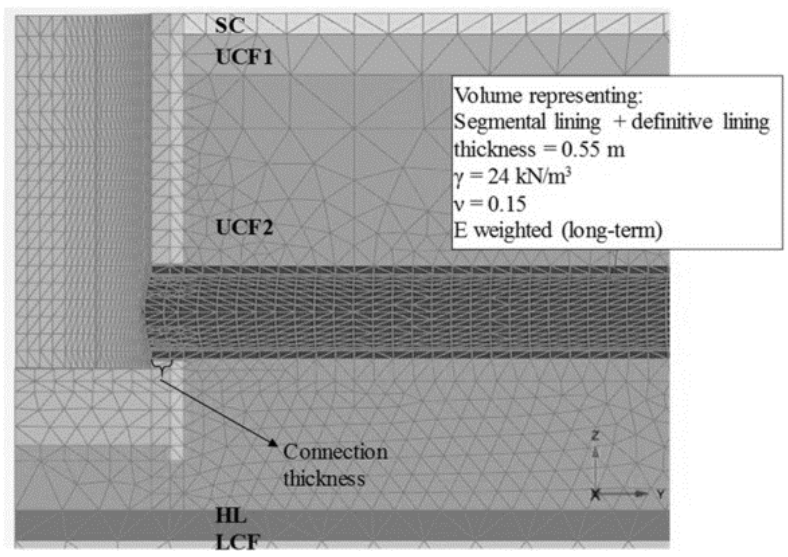

Fig. 4. Tunnel-shaft geometric arrangement for finite element 3D model based on source (Flores, Gordillo, Enríquez, De la Rosa, \& Guasch, 2016)

Comparative Analysis of Shaft Support Stability. In the excavation process of the underground structure, the deformation and stress distribution of the supporting structure can directly reflect the stability of the surrounding rock. Furthermore, different construction programs can produce different changes in the shaft support structure.

To determine the assessment of stresses and strains in the joint, the entire structure and soil layers were considered as volumes (threedimensional clusters) that maintain continuity in all elements, which means that they do not interfere with interface elements, slabs or beams.

In fig. 5 shows the horizontal displacement of the shaft wall at different depths at the end of construction.

a)

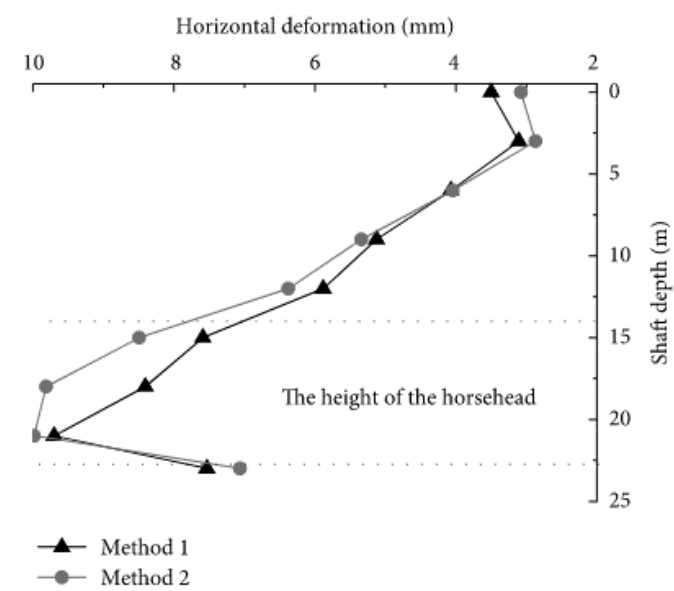

b)

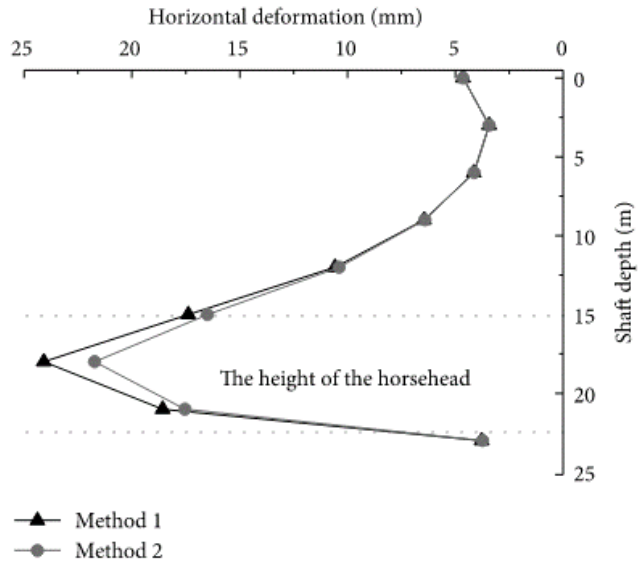

Fig. 5. Deformation of shaft at different depths based on source (Jinxing Lai, et al., 2017)

In fig. 5 (a) shows the change in the horizontal displacement of the shaft wall from the transverse passage in the four walls of the shaft at different depths. In fig. $5(b)$ shows the variation of the horizontal displacement of the shaft wall parallel to the axis of the transverse passage in the four walls of the shaft at different depths. 


\section{Results}

As a "rigid" coupling, the calculation of the tunnel-shaft connection takes into account the concept, after which the concrete volumes of the shaft (building wall + mortar wall) are monolithically connected to the concrete of the tunnel (primary construction + final $y$ construction) (Cárdenas, 2016). The "flexible" coupling takes into account the amount of concrete in the well, which is connected to the concrete in the tunnel by an interface material with elastic properties, modeled as a neoprene ring with linear elastic material properties, with a modulus of elasticity $\mathrm{E}=2 \mathrm{MPa}$, a Poisson's ratio=0.499 and with a thickness $-10 \mathrm{~cm}$ (fig. 7).

The steps for the calculation were as follows:

- First stage: initial conditions for 3D and piezometric model.

- End of shaft excavation construction: installation of a sawn wall with seams, installation of a concrete slab and wall, half-pipe support, ceiling lining and concrete base, condition of excavation drying.

- End of tunnel construction: construction of the corresponding line (primary + final) along the entire length $(135 \mathrm{~m})$. With a soft seal, a $10 \mathrm{~cm}$ thick neoprene ring is attached to the outside of the tunnel, which is in contact with the wall of the shaft.

- Regional settlement: application of long-term piezometry (100 years), shifts are set to zero to observe only long-term effects.

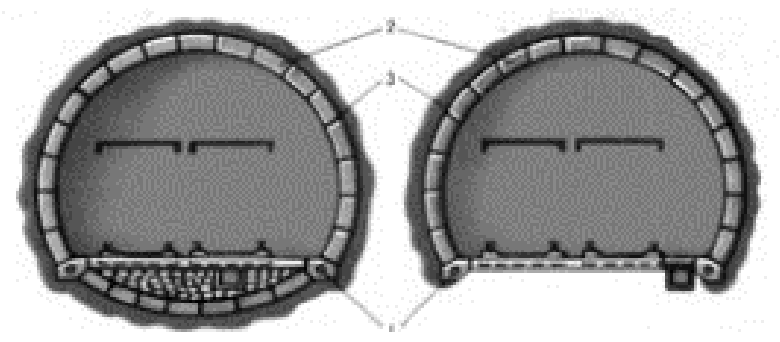

Fig. 6. Modeling of neoprene ring in tunnel-shaft connection based on source (Shu-cai Li, et al., 2016)

If the above calculation steps are performed, the results are obtained of the deformations generated in both types of relatedness. The plastic zone of the surrounding rock mass is an important index for the stability of the material surrounding the tunnel (Song, Yang, \& Jiang, 2016). The plastic distribution of the rock mass surrounding (C) S. M. Stovpnyk, H. K. Tuhanov, 2021 the shaft and cross passage was approximately the same at the end of construction regardless of the construction method used (fig. 7). The large range of the plastic distribution was concentrated in an area that was $0 \ldots 3 \mathrm{~m}$ outside the vertical shaft wall at about the horsehead elevation and $0 \ldots 1 \mathrm{~m}$ in the rock mass surrounding the shaft and invert of the cross passage, the subsidence of the tunnel is equal to the regional subsidence in the free field at that depth.

To compare and analyze the most dangerous position of plastic deformation of surrounding rock resulting from the two construction methods, a plastic deformation value $\geq 100 \mu \varepsilon$ was selected.

a)

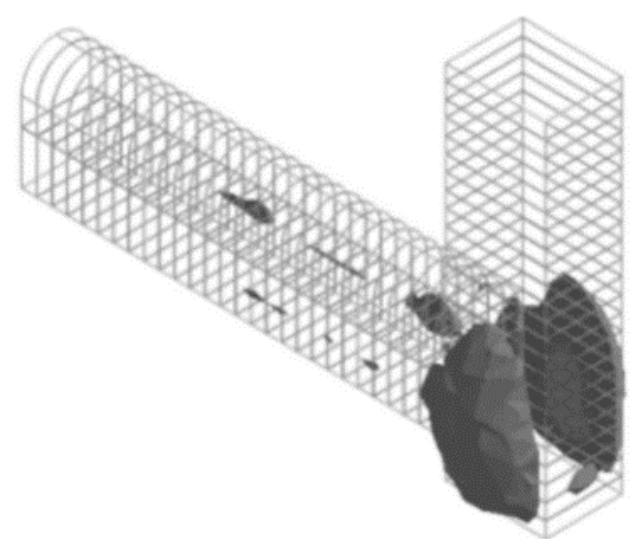

b)

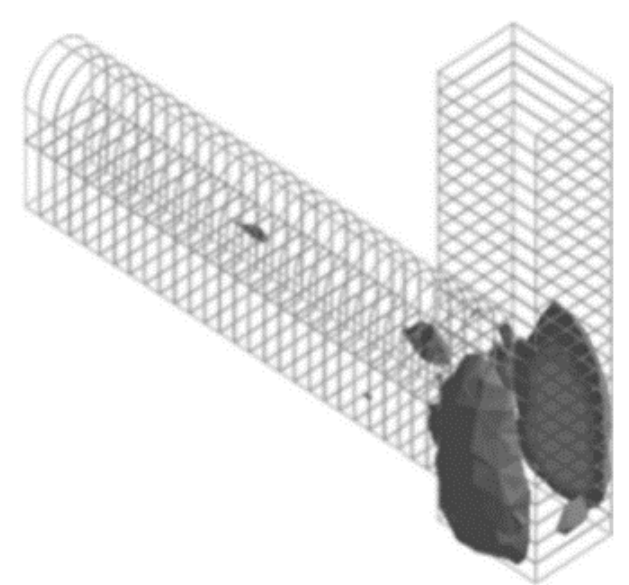

Fig. 7. Plastic zone distribution in surrounding rock

The maximum deformation of the plastic zone in the surrounding rock occurred at the invert of the horsehead when Method 1 was used and at the foot of the top heading of the horsehead when Method 2 was used. Thus, although the overall distribution of plastic deformation in the rock 
surrounding the shaft and cross passage was approximately the same in two construction methods, the locations of the maximum deformation were different. In actual construction, different construction methods need to strengthen

a)

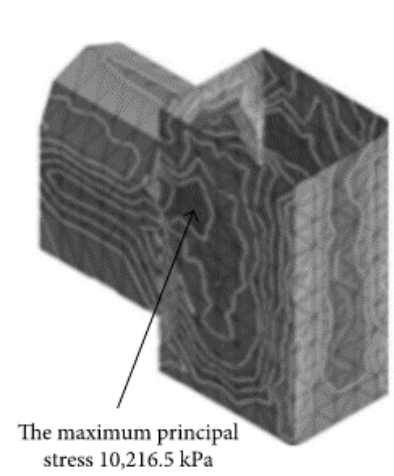

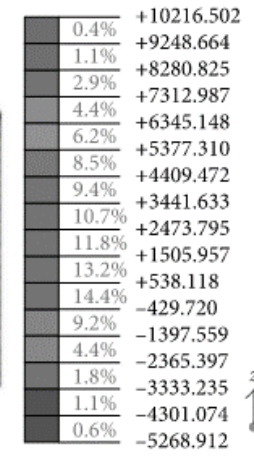

different locations, especially the invert and the foot of the top heading of the horsehead. In addition, the weak rock surrounding the horsehead also needs to be strengthened to prevent the rock surrounding the invert and haunch from collapse.

Fig. 8. Maximum principal stress distribution in the horsehead: $a$ ) Method 1; $b$ ) Method 2

\section{Originality and practical value}

Based on the research drawn based on the results of data analysis from the calculation by the finite element method, a technological solution was put forward. Taking into account the widespread conditions for the construction of metro stations in Ukraine, it is recommended to use a structure with a horizontal connection of the tunnel to the existing shaft using a dynamic depreciation ring.

To implement this method, you must adhere to the following points:

- Ensuring the design position of the shield in the mine. Then penetration to the zone of fixing the shield from the installation of the support part for fixing the shield;

- The shield is mounted from top to bottom;

- Design measures in case of groundwater flooding and their elimination at the site;

- Implementation of the tunnel grout seal and backfill structure;

- Mounting of tunnel elements using flexible insert technology in the field of expansion joints and block lining;

- Based on the data obtained during the calculation by the finite element method, we select the type of attachment at the docking point (flexible connection by a combination of block tunnel lining, monolithic shaft attachment b)

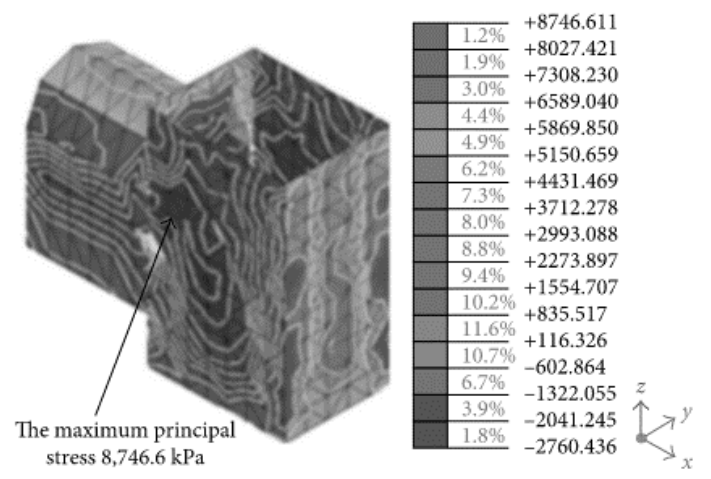

and a flexible insert between them, which in turn makes it possible to work in a field of dynamic deformations up to $150 \mathrm{~mm}$ ).

The simplified model system allowed us to obtain the primary graphs of stresses and strains in the area of interest to us and allowed us to analyze the choice of the type of support and their combination in the conditions of dense urban development on sandy and clayey soils. The flexible joint offers a $20 \%$ advantage over the rigid joint and provides an additional quality offset of $0.15 \mathrm{~m}$.

\section{Conclusions}

The result of this analysis was the conclusion in a high-quality solution for the selection of support and technology of penetration. The method can be more effective with method 2, when first of all the tunnel part is passed, and then the barrel is attached to the tunnel, which gives greater stability of the structure to vertical displacements, but our case does not provide such an opportunity due to the fact that the barrel has already been passed.

The field monitoring data in the aforementioned articles makes it clear that the deformations in the soil do not exceed $15 \mathrm{~mm}$, which in turn meets international safety standards, thus the cross-construction method using 2 types of fastening and a connection in the form of a flexible insert is completely safe and feasible for implementation. 
МОСТИ ТА ТУНЕЛІ: ТЕОРІЯ, ДОСЛІДЖЕННЯ, ПРАКТИКА

\section{REFERENCES}

Arnau, O. \& Peña, F. (2014). Evaluación de daños estructurales en conexión túnel-lumbrera ocasionados por asientos diferenciales. XIX Congreso Nacional de Ingeniería Estructural, SMIE Publication, Puerto Vallarta, Jalisco.

Cárdenas, D. C. (2016). Análisis Numérico de la interacción de estructuras subterráneas en suelos blandos en proceso de consolidación, caso de estudio: Planta de Bombeo "Casa Colorada", (Master degree thesis), Brasilia.

Do, N., Dias, D., Oreste, P., \& Djeran-Maigre, I. (2014). Three-dimensional numerical simulation of a mechanized twin tunnels in soft ground. Tunnelling and Underground Space Technology, 42, 40-51.

Flores, F. A., Gordillo, N. O., Enríquez, O., De la Rosa, J. M., \& Guasch, J. C. (2016). Evaluación del efecto por hundimiento regional en conexiones túneleslumbreras. XXVIII Reunión Nacional de Ingeniería Geotécnica, Publicación SMIG, Mérida, Yucatán.

Jinxing Lai, Haobo Fan, Bangzhe Liu, \& Tong Liu (2011). Analysis of seismic response of shallow large section multi-arch tunnel. Procedia Engineering, 15, 5473-5477.

Jinxing Lai, et al. (2017). Structural safety assessment of existing multiarch tunnel: a case study. Advances in Materials Science and Engineering, 2017(5).

Shu-cai Li, et al. (2016). Large scale three-dimensional seepage analysis model test and numerical simulation research on undersea tunnel. Applied Ocean Research, 59, 510-520.

Song, Z. P., Yang, T. T., \& Jiang, A. N. (2016). Elasticplastic numerical analysis of tunnel stability based on the closest point projection method considering the effect of water pressure. Mathematical Problems in Engineering, 2016(1).

Vahed, G., et al. (2010). Design criteria of subway tunnels. Australian Journal of Basic and Applied Sciences, 4(12), 5894-5907.

Zaldivar, S. F., Rodríguez, J. F., \& Auvinet, G. (2012). Análisis numérico de la interacción lumbrera-túnel en suelos blandos sometidos a hundimiento regional. Memorias XXVI Reunión Nacional de Ingeniería Geotécnica, Publicación SMIG, Cancún, Quintana Roo.

\section{С. М. СТОВПНИК ${ }^{1 *}$, Г. К. ТУГАНОВ ${ }^{2}$}

1* Національний Технічний Університет України «Київський Політехнічний Інститут ім Ігоря Сікорського», просп. Перемоги, 37, Київ, Україна, 03056, тел.+380503107825, e-mail stansto@i.ua, ORCID 0000-0001-8053-2653

$21^{*}$ Національний Технічний Університет України «Київський Політехнічний Інститут ім Ігоря Сікорського», просп. Перемоги, 37, Київ, Україна, 03056, тел.+380999654631, e-mail girey007@ gmail.com, ORCID 0000-0002-8048-0635

\section{АНАЛІЗ КОМБІНАЦІї ЕЛЕМЕНТІВ З'ЄДНАННЯ У ТОЧКАХ КРІПЛЕННЯ ТУНЕЛЮ 3 ВЕРТИКАЛЬНИМ СТВОЛОМ В УМОВАХ ЩІЛЬНОЇ МІСЬКОЇ ЗАБУДОВИ}

Мета. Визначити проблему порівняння довготривалої поведінки горизонтальної виробки тунелю 3 урахуванням жорстких i гнучких зв'язків у проектованих конструкціях в Україні 3 3D цифровим моделюванням за допомогою тривимірного методу скінченних елементів. Також розроблено уточнену геотехнічну модель 3 урахуванням природи п'єзометричних вихідних умов i запропонованих п’єзометричних умов для оцінки довгострокового стану, а також зведення властивостей навантажень у грунті з урахуванням розмірів тунелю та ствола. Методика. Аналіз конструктивних зв'язків на основі досвіду будівництва мілкого закладання в умовах щільної міської забудови на прикладі будівельних об'єктів Китаю та Мексики. Пошук оптимального поєднання впроваджених методів для досягнення оптимального результату. Вибір режиму роботи конструкції з тривимірним цифровим моделюванням, тривимірним методом скінченних елементів на основі двох припущень; перше припущення розглядає жорстке з'єднання як монолітну бетонну конструкцію між стінкою стволу та тілом тунелю, а друге припущення розглядає матеріал $з$ пружною поведінкою між двома конструкціями, що, у свою чергу, призводить до гнучкого з'єднання. Визначаються основні параметри, які необхідно уточнити та виправити проектувальником системи при введенні в експлуатацію. Далі модель грунту була використана для проведення аналізів 3 кінцевими елементами для стиснутих шарів грунту. Результати. При моделюванні в програмному середовище Plaxis, отримали графіки перехідних процесів для найважливіших робочих параметрів, таких як геометрія тунелю та необхідна жорсткість полімерної деформаційної прокладки, флотаційний пул, тривимірні кластери. Наукова новизна. Наукова зацікавленість до розвитку технологій, що до цього моменту не розглядались у використанні в комбінації між собою. Розробка алгоритму оптимального підбору (C) S. M. Stovpnyk, H. K. Tuhanov, 2021 
параметрів гнучкості та довговічності в конкретних умовах, для економії часу та спрощення розрахункових форм. Практична значимість. Проведено аналіз отриманих результатів, основна увага приділена відносним навантаженням і концентраціям напружень у з'єднувальних елементах, а саме напруженнях, що виникають у поперечному напрямку з'єднання. Також у статтях було визначено деякі переваги та недоліки різних варіантів підключення, які обговорюються з метою нейтралізації впливу в майбутньому.

Ключові слова: 3’єднання «тунель - ствол»; жорстке з'єднання; гнучке з'єднання; слабкі грунти; щільна міська забудова

\section{REFERENCES}

Arnau, O. \& Peña, F. (2014). Evaluación de daños estructurales en conexión túnel-lumbrera ocasionados por asientos diferenciales. XIX Congreso Nacional de Ingeniería Estructural, SMIE Publication, Puerto Vallarta, Jalisco. (in Spanish)

Cárdenas, D. C. (2016). Análisis Numérico de la interacción de estructuras subterráneas en suelos blandos en proceso de consolidación, caso de estudio: Planta de Bombeo "Casa Colorada", (Master degree thesis), Brasilia. (in Spanish)

Do, N., Dias, D., Oreste, P., \& Djeran-Maigre, I. (2014). Three-dimensional numerical simulation of a mechanized twin tunnels in soft ground. Tunnelling and Underground Space Technology, 42, 40-51. (in English)

Flores, F. A., Gordillo, N. O., Enríquez, O., De la Rosa, J. M., \& Guasch, J. C. (2016). Evaluación del efecto por hundimiento regional en conexiones túneles-lumbreras. XXVIII Reunión Nacional de Ingeniería Geotécnica, Publicación SMIG, Mérida, Yucatán. (in Spanish)

Jinxing Lai, Haobo Fan, Bangzhe Liu, \& Tong Liu (2011). Analysis of seismic response of shallow large section multi-arch tunnel. Procedia Engineering, 15, 5473-5477. (in English)

Jinxing Lai, et al. (2017). Structural safety assessment of existing multiarch tunnel: a case study. Advances in Materials Science and Engineering, 2017(5). (in English)

Shu-cai Li, et al. (2016). Large scale three-dimensional seepage analysis model test and numerical simulation research on undersea tunnel. Applied Ocean Research, 59, 510-520. (in English)

Song, Z. P., Yang, T. T., \& Jiang, A. N. (2016). Elastic-plastic numerical analysis of tunnel stability based on the closest point projection method considering the effect of water pressure. Mathematical Problems in Engineering, 2016(1). (in English)

Vahed, G., et al. (2010). Design criteria of subway tunnels. Australian Journal of Basic and Applied Sciences, 4(12), 5894-5907. (in English)

Zaldivar, S. F., Rodríguez, J. F., \& Auvinet, G. (2012). Análisis numérico de la interacción lumbrera-túnel en suelos blandos sometidos a hundimiento regional. Memorias XXVI Reunión Nacional de Ingeniería Geotécnica, Publicación SMIG, Cancún, Quintana Roo. (in Spanish)

Надійшла до редколегії 19.10.2021.

Прийнята до друку 05.11.2021. 